\title{
PIEZO2 Gene
}

National Cancer Institute

\section{Source}

National Cancer Institute. PIEZO2 Gene. NCI Thesaurus. Code C106086.

This gene is involved in the response to mechanical stimuli. 